\title{
The Most Devastating of Life's Disasters
}

\author{
Jack Kushner* , Prof Med, MD, MGA, FACS, FICS, FAANS, HDG \\ Professor of surgery, Cambridge University, Maryland, USA
}

Submission: February 9, 2018; Published: February 26, 2018

*Corresponding author: Jack Kushner, Annapolis, Maryland, USA, Email: jkaoportal@comcast.net

\section{Abstract}

Spinal Cord Injuries are the most devastating of life's disasters. Three different case histories are presented. The effect these injuries have on our society from both an emotional and economic point of view is discussed. Examples are given of just how some patients and their families have adapted to their circumstances.

Keywords: Spinal Cord Injuries

\section{Introduction}

Robin was 18 years old at the time of his injury. He was working at the Rainbow Cleaners located in Annapolis, Maryland when one late afternoon, a customer walked into the store. He demanded all of the money in the store and Robin complied. Then the thief told Robin to turn around which he did, but then the thief shot Robin in the back of the neck causing an immediate paralysis below the neck. In just a few fateful minutes, Robin's life was turned upside down. After the thief escaped another customer entered the store and found Robin on the floor. The customer called 911 to obtain help from the Emergency Medical service and the police. The Emergency Medical service took Robin to the Anne Arundel General Hospital and I was called. Robin was examined and found to be tetraplegic with a gunshot wound to the back of the neck. X-rays obtained showed a bullet lodged right next to the C6-C7 vertebrate. Arrangements were made to transfer Robin to the operating room where he was placed on the operating table after being anesthetized. A posterior cervical surgical procedure was performed and the bullet removed from its adjacent position next to the vertebrate. The spinal cord was examined and the dura was opened more so as to examine the spinal cord itself. The spinal cord was bruised and was slightly hemorrhagic, but it was not transected. The dura was repaired and a good closure was obtained. The remainder of the wound was debrided and closed. Robin was treated with steroids, intravenous fluids, and antibiotics. Although initially tetraplegic, as each day progressed Robin seemed to acquire some partial movement in his extremities. Physical therapy was started and day-by-day Robin improved. He remained paralyzed below the C6-C7 level. As time went on, Robin was able to make adjustments with hand brakes in his automobile so that he could safely drive. He then went on to George Washington University where he commuted to class for four years and graduated. For many years he was able to work in the insurance and real estate fields and to support his family until eventually he was appointed as Director of the State of Maryland's Criminal Victim's Compensation Fund.

Although there is some evidence that the ancient Egyptians thought about treating patients with spinal cord injuries, there is more evidence that they felt that this condition was hopeless and should not be treated at all. It was probably not until the time of a Greek physician, Hippocrates, that a form of traction and immobilization was attempted[1]. No significant advances were made in the treatment of spinal cord injuries until 1846, when Ignaz Philipp Semmelweis began working at the General Hospital in Vienna, Austria and brought the infection issue to the forefront of medicine. Semmelweis observed that the mortality rate for women who were cared for by medical students was lower than the mortality rate for women who delivered babies, and who were cared for by midwifery pupils, who did not wash their hands and carried infectious material from patient to patient. In 1847, Semmelweiss made it mandatory that medical students and doctors washed their hands in between performing autopsies and delivering babies and prior to going to different patients. A few years before Semmelweiss wrote a book on this subject, Oliver Wendell Holmes (1809-94) gave a lecture in Boston suggesting that childhood fever was an infection caused by "germs". Many doctors doubted these ideas, but were finally convinced that pathogens did cause infection in 1879 , by none other than Louis Pasteur [2]. Even so, in WWI, 90 per cent of the patients who had a spinal cord injury died within one year of the injury and only 1 per cent of these patients survived for 20 years [3]. Since that time, patients have been living longer with these injuries, but still severely incapacitated. There have been improvements in 
the general medical care of all patients with the development of antibiotics, respirators, and in physical therapy techniques.

Although there were many such injuries in WWII, one of the more publicized was that involving General George S. Patton, Jr. On December 9, 1945, General Patton was riding as a passenger in the back seat of a Cadillac limousine. After waiting at a railroad junction for a long train to pass, suddenly an Army truck made a left turn right into the Cadillac not going even twenty miles an hour. But this accident threw General Patton into the steel frame of the partition causing a severe laceration of the scalp which resulted in a great deal of blood loss. More importantly, Patton told Major General Hobart R. Gay who was riding with him that he was having trouble breathing and wanted Gay to work his fingers for him. Shortly afterward, an army ambulance arrived with Captain Ned Snyder, a medical officer. Dr. Snyder found General Patton motionless in the back seat of the car. Patton told the doctor that he thought he was paralyzed. Dr. Snyder diagnosed that Patton had a broken neck and ordered him to be bundled up and transferred to the outskirts of Heidelberg to the new station hospital of the Seventh Army. Patton was conscious during the whole ordeal and was very quiet during the twenty five minute trip to the hospital operated by the 130th Station Hospital with Colonel Lawrence C. Ball as the commanding officer [4]. Lieutenant Colonel Paul S. Hill, Jr., chief of the surgical service, took over the management of this case immediately. Upon examining General Patton, Dr. Hill found him to have cyanotic lips and cold feet with his neck being flexed forward. Because Patton was in shock, Dr. Hill had him transfused with $1500 \mathrm{cc}$. of plasma and $300 \mathrm{cc}$.of whole blood type A from four GI donors. Color returned to Patton's face and his blood pressure returned to 110 over 76, whereas it had been only 86 over 80 upon arrival. Dr. Hill then proceeded to deal with the huge scalp wound which was a Y shaped laceration.

Then Dr. Hill wenton to do a more detailed physical examination. There was no evidence of any long bone fractures. There was a flaccid paralysis of all the muscles of the thorax, abdomen, and the extremities. There was no sensation below the clavicles and he did not have any deep tendon reflexes. Patton was not able to move any of his extremities. A neurosurgeon, Captain William R. Duane, Jr, examined the patient and the x-rays. He diagnosed that the third and fourth cervical vertebrate were fractured and dislocated and that the spinal cord had been transected. Crutchfield tongs were placed in the skull which would hold pounds of traction in order to attempt to reduce the fracture dislocation. The urinary bladder needed to be emptied and an indwelling catheter was inserted. Penicillin was administered as well. Dr. Hill told the others that General Patton would not recover and would not live very long. Spinal cord injuries accounted for approximately twelve per cent of neurosurgical casualties in WWII, a number higher than anticipated. Initially, thee was no inclination to explore these injuries surgically and many neurosurgeons questioned the value of any surgical exploration. But there were others who felt that surgery might just help and that it would be beneficial to remove bone fragments from the spinal cord itself and to debride any dead tissue in order to decrease the chances of an infection. Eventually those who favored surgical exploration prevailed. During WWII, the Army Medical Corp adopted the policy of exploring wounds to the brain and to the spinal cord when there was reasonable doubt concerning the extent of the damage to the central nervous system. The author of this policy was Dr. R. Glen Spurling from Louisville, Kentucky who had given up his practice after Pearl Harbor was attacked and served as a neurosurgical consultant in Europe during the war. He worked with Dr. Barnes Woodhall who became Chief of Neurosurgery at Duke University, but by December, 1945, neither of them was in Europe.

The Surgeon General in Washington was able to contact the War Office in London to request that Brigadier Hugh Cairns, professor of Neurosurgery at Oxford University School of Medicine consult on this case. An Army plane was sent to London and on December 10, Brigadier Cairns flew to Heidelberg. Cairns then examined Patton and his findings confirmed earlier exams. Professor Cairns felt that the patient had an incomplete lesion at the fifth cervical vertebrate and that the third cervical vertebrate had also been fractured. Professor Cairns felt that there was reason to be hopeful when he detected that Patton had felt the tapping of the right patellar tendon and the pinching of the right thoracic skin. Since they were having difficulty keeping the Crutchfield tongs in place, Professor Cairns recommended that they use zygomatic hooks instead which are ordinary fish hooks fixed into the cheekbones which were uncomfortable since they now had ten pounds of weight on them. General Eisenhower arranged for Spurling to fly to Germany with Mrs. Patton. No one believed that Spurling could add anything else but they felt Mrs. Patton just might improve Patton's spirits. On December 12, Spurling examined Patton and found that he was paralyzed, but there was some voluntary motion of the right biceps muscle. He detected some deep sensation in his arms and legs. The deep tendon reflexes had returned and were hyperactive in both legs. He detected a definite sweating at the $\mathrm{C} 5$ dermatome and the most recent $\mathrm{x}$-rays showed a complete realignment of the cervical spine. Patton's general condition had stabilized as the temperature and the blood pressure were normal. Patton was able to breathe on his own. Fourteen hours later, Patton's condition deteriorated at which point Spurling became less optimistic.

By December 17 at 7:00 PM, Captain Duane found that Patton had improved. He detected some movements in the left quadriceps muscle and in the right abductor group of muscles. Patton was positioned in a 45 degree angle and was able to take some liquids by mouth such as soup. On December 19, he was able to eat an egg and drink a cup of coffee. On December 18, his vital signs appeared to be normal with a blood pressure of 108 over 70 . Colonel Spurling cabled Dr. Michael DeBakey who was a 37 year old assistant professor of surgery at Tulane University serving as a colonel in the office of the Surgeon General about arrangements for Patton's care in the United States. Later that night, Patton 
started coughing and bringing up bloody sputum. Colonel Spurling diagnosed an infarction of the lungs due to a pulmonary embolus. This is a piece of clotted blood that can lodge in the heart or in the brain and bring on instant death. By the morning of December 20, Patton was given Atropine and oxygen as well as saline and blood, but nothing helped him. General Patton died December 21, 1945 at $17: 45$.

Dean was a teenager of 16 years when he dove into unknown waters near his home on the Magothy river near Annapolis, Maryland. He was rendered tetraplegic immediately when his neck was acutely flexed as he hit the bottom of the river. He was flown to the Shock-Trauma Center at the University of Maryland and received immediate treatment. In addition, he had an iliac bone graft to his posterior cervical spine area in order to fuse the vertebrate at $\mathrm{C} 5-\mathrm{C} 6$ where there was a fracture dislocation. Afterwards he received rehabilitation and physical therapy. He later married a nurse at the Anne Arundel Medical Center. I met this couple at the Naval Academy golf driving range where she was practicing golf drives and he was observing in a wheelchair which she managed to remove from their SUV.

It is estimated that 11,000 spinal cord injuries occur each year in the United States, and that approximately there are a quarter of a million Americans living with this catastrophic injury [5]. The records indicate that the average age at the time of injury has increased from 28 years to 38 years. More people over the age of 60 are having these injuries mainly due to auto accidents and falls. Only a small percentage of the victims are children. Based on reports from the NSCISC, the major causes of these injuries are due to automobile crashes, falls, violent acts, gunshot wounds, and recreational sports. Probably because of the preventive attention called to these problems by insurance companies and others, there has been a decline in the number of work related injuries resulting in spinal cord injuries and there has been an increase in the number of spinal cord injuries resulting from recreational sports such as football. The higher the level of injury to the spinal cord, the more severe will be the disability. For example, a C4-5 injury will result in the loss of movement in the arms and perhaps difficulty in breathing in some patients. In addition, the patients with lesions at this level will have no sensation below C4-5, no deep tendon reflexes, no superficial abdominal reflexes, no bowel or bladder control, and no movement in the lower extremities. A patient with a lower lesion at T12-L1 will retain strength and movement in his arms and will retain deep tendon reflexes in his arms. He will not have difficulty breathing and may very well have some superficial abdominal reflexes. He will not be able to move his legs and will not have bowel nor bladder control. Estimating the costs of these injuries to society is more difficult due to the decrease in the value of the American dollar and the increase in inflation. According to Berkowitz [6], the costs for the first year of care after such a devastating injury can be close to $\$ 2,500,000$ and then the annual costs for the care of such a patient can be close to $\$ 4.500,000$ with an additional indirect costs amounting close to another \$2,500,000 annually.

How does the incidence of spinal cord injuries compare with the incidence of other tragic diseases? According to some reports, if there are a quarter of a million spinal cord cases in the United States requiring chronic care, there are about 400,000 cases of multiple sclerosis, 2.3 million cases of epilepsy, half a million cases of Parkinson's disease, 4.5 million cases of Alzheimer's disease, and 5.4 million stroke patients [6-11]. Unfortunately, there is no way to reverse damage to the spinal cord. Intravenous methylprednisolone has been used as a treatment option for a spinal cord injury, but recent research has demonstrated the potential side effects such as blood clots and pneumonia. Hence steroids are no longer recommended after a spinal cord injury. Some experimental treatments are still under investigation such as hypothermia and stem cell therapy. In addition, rehabilitation involves the use of electrical stimulation devices to control arm and leg muscles. Robotic gait training and computer adaptations are also used in some medical centers. Finally, spinal cord injury treatment should also focus on preventing such an injury.

\section{References}

1. Eltorai IB (2002) History of spinal cord medicine. In: Lin V, Cardenas DD, Cutter NC.

2. Haeger Knut (1988) The Illustrated History of Surgery, Bell Publishing Company, New York, USA, pp. 204-205.

3. Grundy D, Swain A [Eds.] (1986) ABC of Spinal Cord Injury ( $4^{\text {th }}$ edn), British Journal of Medicine, London, p. 1-4.

4. Farago, Ladislas (1981) The Last days of Patton, McGraw-Hill Book Company, New York, pp. 245-294.

5. NSCISC-National Spinal Cord Injury Statistical Center (2004) Facts and figures at a Glance.

6. Berkowitz M, Harvey C, Greene CG, Wilson SE (1998) Spinal cord Injury; An Analysis of Medical and Social Costs, Demos Medical Publishing, New York.

7. Ernst RL, Hay JW (1994) The US economic and social costs of Alzheimer's disease revisited. American Journal of Public Health 84(8): 1261-1264.

8. Hebert LE, Beckett LA, Scherr PA, Evans DA (2001) Annual incidence of Alzheimer disease in the United States projected to the years 2000 through 2050. Alzheimer Disease \&Associated Disorders 15(4): 169173.

9. National Multiple Sclerosis Society (2004) National Multiple Sclerosis Society.

10. Frost FS, Hammond MC, Lindblom LB, Perkash I, Waters R [Eds.] Spinal Cord Medicine: Principles and Practice. Demos Medical Publishing, New York, p. 3-14.

11. NSCISC-National Spinal Cord Injury Statistical Center (2004) Facts and figures at a Glance. 
CC (P) This work is licensed under Creative (c) Commons Attribution 4.0 License

DOI: 10.19080/JOJNHC.2018.06.555687

\section{Your next submission with Juniper Publishers} will reach you the below assets

- Quality Editorial service

- Swift Peer Review

- Reprints availability

- E-prints Service

- Manuscript Podcast for convenient understanding

- Global attainment for your research

- Manuscript accessibility in different formats

( Pdf, E-pub, Full Text, Audio)

- Unceasing customer service

Track the below URL for one-step submission https://juniperpublishers.com/online-submission.php 